\title{
BTB/POZ Domain-Containing Protein 18
}

National Cancer Institute

\section{Source}

National Cancer Institute. BTB/POZ Domain-Containing Protein 18. NCI Thesaurus. Code C126631.

BTB/POZ domain-containing protein $18(712 \mathrm{aa}, \sim 78 \mathrm{kDa})$ is encoded by the human BTBD18 gene. This protein may be involved in the regulation of ubiquitination. 